\title{
Determination of Heavy Metals and Lanthanides in Indian Tea by Inductively Coupled Plasma Mass Spectrometry (ICP-MS)
}

\author{
Rupali A. Lagad ${ }^{\text {a }}$ D. Alamelua ${ }^{\mathrm{a}}$, Ashwini K. Chaudhary ${ }^{\mathrm{b}}$, and Suresh K. Aggarwal ${ }^{\text {a* }}$ \\ ${ }^{a}$ Fuel Chemistry Division, Bhabha Atomic Research Centre, \\ Trombay, Mumbai 400 085, India \\ b Institute Instrumentation Centre, Indian Institute of Technology, \\ Roorkee 247 667, India
}

\section{INTRODUCTION}

Medicinal plants and their extracts play a major role in the maintenance of human health and serve as a primary source for health care. According to the World Health Organization (WHO) report, almost $80 \%$ of the people living in marginal communities use only medicinal plants for the treatment of various diseases (1). Tea, obtained from the plant Camellia sinensis, is recognized as one of the medicinal plants in Indian traditional medicine. Green tea is a widely used herbal medicine both for prevention and treatment of many ailments. Tea contains flavonoids, minerals, and trace elements that are essential to human health. Studies have shown that tea contains antioxidants and healthpromoting ingredients that can play a major role in the prevention of many diseases such as skin cancer, Parkinson's disease, myocardial infarction, and coronary artery disease (2).

Extensive industrialization usually results in the emission of various pollutants to the environment, leading to high anthropogenic emission of heavy metals into the biosphere (3). Lanthanides represent an interesting group of elements. Their use is steadily growing in a number of fields such as glass manufacturing, petroleum refining, supercondutor, and the nuclear industry (4) and are released into the environment mainly due to coal burning (5). Extensive use of inorganic com-

\footnotetext{
*Corresponding author.
}

E-mail: skaggr2002@rediffmail.com, skaggr2002@gmail.com

\section{ABSTRACT}

In the present work, six heavy metals (Mo, Cd, Sb, Tl, Pb, and $\mathrm{Bi}$ ) and eight lanthanides (La, Ce, $\mathrm{Pr}, \mathrm{Nd}, \mathrm{Sm}, \mathrm{Gd}, \mathrm{Dy}$, and $\mathrm{Yb}$ ) were determined at ng $\mathrm{g}^{-1}$ levels in 77 Indian tea samples using inductively coupled plasma source mass spectrometry (ICP-MS) after microwave digestion of the solid samples. The samples included virgin tea leaves and processed tea samples collected from teaproducing regions as well as some commercially available in the market. The analytical procedure was validated by analyzing the certified reference material GSB-7 Tea Leaves.

The results of the present work show that the heavy metal and lanthanide concentrations in tea samples from India, present at ng g ${ }^{-1}$ levels, are comparable to tea obtained from other tea-producing regions in the world. Due to the low extraction efficiency of heavy metals and lanthanides, their daily limit of intake was found to be below the WHO permissible intake values (Cd $11 \mathrm{ng} /$ day, Mo $24.2 \mathrm{ng} / \mathrm{day}, \mathrm{Sb}$ $6.4 \mathrm{ng} / \mathrm{day}, \mathrm{Tl} 18-75.7 \mathrm{ng} / \mathrm{day}$, $\mathrm{Pb} 200-300 \mathrm{ng} / \mathrm{day}$, and $\mathrm{Bi}$ 8-16 ng/day). The significant differences in the elemental concentration of heavy metals and lanthanides from the different tea-producing regions give an indication of the different degree of pollution in these regions. pounds, such as $\operatorname{REE}\left(\mathrm{NO}_{3}\right)_{2}$ as a microelement fertilizer, accumulates in the ecosystem and then becomes harmful (6).

Tea plants take up various elements, including heavy elements, from the soil through their roots. These elements are then transferred to the different parts of the plant and transformed into physiologically tolerable forms. Many studies have reported on the determination of essential elements in tea leaves and their infusions, and have also discussed the potential health implication of heavy metals in tea (7-12).

The extent of physiological disturbance depends upon uptake and bioaccumulation of the metals. Chronic metal toxicity is characterized by tissue/organ damage resulting in mortalities that are related to secondary physiological disturbances (13). Heavy metals can also enter the food chain through bioaccumulation. Dietary intake of heavy metals through contaminated food may lead to various chronic diseases depending on the concentrations and oxidation states of the heavy metals, and the types of sources and modes of deposition (14). Chronic exposure to high levels of cadmium (Cd) can lead to emphysema, bronchiolitis, and alveolitis (15). In the case of lanthanides, acute toxicity and subchronic toxicity tests showed that low doses of rare earth elements (REEs) had no significant teratogenity and mutagenicity (16). However, there are no precise evaluations of the long-term biological effects of REEs on plants, animals, and humans. Hence, the determination 
of heavy metals and lanthanides is considered essential with regard to their daily intake and safety regarding health.

In this work, the results obtained for the heavy metals and the lanthanides by inductively coupled plasma mass spectrometry (ICP-MS) in 77 Indian tea samples are presented, which includes market samples as well as those collected from the field (virgin tea leaves and processed tea from tea estates). It may be noted that the processed tea samples used in this work are commercially available in India under different brand names, and a few of these are also exported to other countries. The data obtained in the present work is useful to ascertain the safety of Indian tea for human consumption. Due to the low detection limits and fast analysis, ICP-MS is an attractive method for lanthanide and heavy metals determination at trace levels and was employed for this work.

\section{EXPERIMENTAL}

\section{Standard Solutions, Reagents, and Samples}

Standard solutions (with concentrations of $10 \mathrm{ng} \mathrm{mL}^{-1}$ of the different heavy elements), samples, and the blank solutions were prepared in $2 \%$ Suprapur ${ }^{\circledR} \mathrm{HNO}_{3}$ (obtained from E. Merck, Darmstadt, Germany) and using Milli- $\mathrm{Q}^{\mathrm{TM}}$ water. In order to obtain the sensitivity factors for the different elements, a calibration solution (10 $\mu \mathrm{g} / \mathrm{L}$ concentration) was prepared from the ICP-MS multi-element stock standard solution (E. Merck). In the present study, indium (In) was employed as an internal standard. Certified reference material (CRM) GSB-7 Tea Leaves, obtained from the Bureau of Analyzed Samples (Middlesbrough, UK) was used to validate the analytical procedure. All containers were cleaned by leaching with $10 \% \mathrm{HNO}_{3}$ and rinsed several times with Milli-QTM ${ }^{\mathrm{TM}}$ water before use.

\section{Tea Sample Preparation}

Seventy-seven tea samples from different regions of India were analyzed. Virgin tea leaf buds and processed tea leaf samples were collected from Assam (Northeast), Darjeeling (Northeast), Munnar (South), and Kangra (Northwest). Twenty-one brand-named tea samples available in the supermarket and of unknown origin in India were also analyzed. The tea samples from Munnar consisted of black and green tea.

Weighed amounts (about $0.25 \mathrm{~g}$ ) of each of the tea samples was digested in a Multiwave ${ }^{\circledR} 3000$ microwave digestion system (Anton Paar, Graz, Austria), equipped with temperature and pressure regulation, and using a mixture of $3 \mathrm{~mL}$ of Suprapur $\mathrm{HNO}_{3}$ and $1 \mathrm{~mL}$ of high purity $\mathrm{H}_{2} \mathrm{O}_{2}$ (E. Merck). A maximum power of 500 watts was used, which yielded a maximum temperature of $190{ }^{\circ} \mathrm{C}$ and a pressure of 25 bar. The total run time for the program was about 105 minutes. After digestion, the sample vessels were cooled, vented, and opened. The clear solutions were transferred into pre-leached polypropylene bottles and diluted to $25 \mathrm{~mL}$ with $1 \mathrm{M} \mathrm{HNO}_{3}$. To avoid deposition on the cones during ICP-MS analysis, the solutions were further diluted five times, i.e., the concentration of the elements in each gram of solid sample was diluted by about 500 times for ICP-MS analysis. CRM GSB-7 Tea Leaves, which was employed for validation of the analytical procedure for heavy metals content, was also digested employing the same procedure as that used for the samples. To each standard, sample, and blank, indium was added as an internal standard for a final concentration of $10 \mathrm{ng} / \mathrm{mL}$ In. All of the sample preparation steps were carried out in a clean lab (class 100) to avoid any contamination.

\section{ICP-MS Analysis}

The measurements were carried out using the ELAN ${ }^{\circledR}$ DRC TM $^{\text {TM }}$ quadrupole-based ICP-MS (PerkinElmer, Inc., Shelton, CT, USA). To account for drift, such as variation in the intensities of the different elements with the time (which was found to vary about $10 \%), 10 \mathrm{ng} \mathrm{g}^{-1}$ of ${ }^{115}$ In internal standard was added to the standard and sample solutions during the analysis and the standard-sample-standards bracketing method was employed for obtaining the concentrations in the samples. The relative sensitivity values of the different elements w.r.t. In obtained during the analysis period of around 7 hours are shown in Figure 1a (heavy elements) and $1 \mathrm{~b}$ (lanthanides). The measurements of the standard solutions were repeated after measurement of five samples. The typical instrumental conditions and measurement parameters used in this work are listed in Table I.

\section{RESULTS AND DISCUSSION}

Table II shows the results for CRM GSB-7 Tea Leaves using the Relative Sensitivity Factors (RSFs) data w.r.t. In, which was determined using the multielement standard solutions (MES) containing

${ }^{115}$ In as an internal standard. The accuracy of the measurements of heavy elements in the tea samples was evaluated by analyzing three independently digested samples of the certified reference material. Good agreement between the experimentally obtained and certified values indicated reliability of the analytical method. Precision of the measurements was determined by replicate analyses of the GSB-7 Tea Leaves standard and is given as $\%$ relative standard deviation (\% RSD) in Table II. The limits of detection (LODs) for the different elements are also listed in Table II, 


\section{Atomic Apectroscopy \\ $\bigcirc$ Vol. 33(4), July/August 2012}

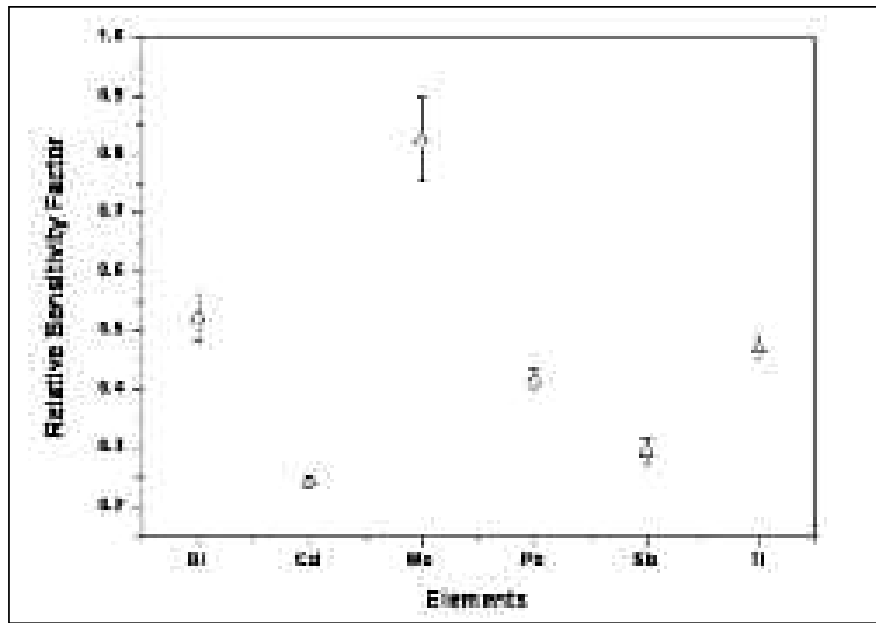

Fig. 1a. Variation in relative sensitivity factors of beavy metals for the period of 7 hours of ICP-MS analysis.

TABLE I

ICP-MS Instrumental Parameters

\begin{tabular}{ll}
\hline Parameters & Data \\
\hline $\begin{array}{l}\text { Nebulizer, } \\
\text { Sample uptake rate } \\
\text { (peristaltic pump) }\end{array}$ & Concentric, $1 \mathrm{~mL} / \mathrm{min}$ \\
Spray chamber & \\
Nebulizer gas flow & Scott double pass \\
Auxiliary gas flow & $0.95 \mathrm{~L} \mathrm{~min}{ }^{-1}$ \\
Plasma gas flow rate & $1.05 \mathrm{~L} \mathrm{~min}{ }^{-1}$ \\
RF power & $13.00 \mathrm{~L} \mathrm{~min}{ }^{-1}$ \\
Sample and skimmer cones & Nickel \\
Internal standard & In \\
Measured Isotopes & ${ }^{98} \mathrm{Mo},{ }^{114} \mathrm{Cd},{ }^{121} \mathrm{Sb},{ }^{205} \mathrm{Tl}$, \\
& ${ }^{208} \mathrm{~Pb},{ }^{209} \mathrm{Bi},{ }^{139} \mathrm{La},{ }^{140} \mathrm{Ce}$, \\
& ${ }^{141} \mathrm{Pr},{ }^{142} \mathrm{Nd},{ }^{152} \mathrm{Sm}$, \\
& ${ }^{158} \mathrm{Gd},{ }^{164} \mathrm{Dy},{ }^{174} \mathrm{Yb}$ \\
\hline
\end{tabular}

calculated as three times the standard deviation $(3 \sigma)$ of 10 replicates of the blank solution. It should be noted that the concentration of thallium in CRM GSB-7 is an information value, $50 \mathrm{ng} \mathrm{g}^{-1}$, and the experimental result, $48.6 \pm 2.5 \mathrm{ng} \mathrm{g}^{-1}$ of $\mathrm{Tl}$, is close to the value mentioned in the certificate.

Quantification of the heavy metals and lanthanides was done by using relative sensitivity factors (RSFs) of the different elements obtained with respect to indium
( ${ }^{115}$ In). Figure 2 shows a comparison between variation in mean relative sensitivity values and mean sensitivity of heavy metals and lanthanides during a period of 7 hours of ICP-MS analysis. The ratios of sensitivities of the different elements w.r.t. ${ }^{115}$ In as an internal standard gave more precise results (RSD of $\leq 5 \%$ ) as compared to those obtained using the sensitivities of the elements during ICP-MS analysis (RSD of $\leq 10 \%$ or more). The concentrations of 14 elements, which includes six heavy metals (Mo, Cd,
TABLE II Elemental Concentrations in CRM GSB-7 Tea Leaves

\begin{tabular}{ccccc}
\hline Element & $\begin{array}{c}\text { Determined } \\
\left(\mathrm{ng} \mathrm{g}^{-1}\right)(\mathrm{n}=3)\end{array}$ & $\begin{array}{c}\text { Certified } \\
\left(\mathrm{ng} \mathrm{g}^{-1}\right)\end{array}$ & $\begin{array}{c}\text { RSD } \\
(\%)\end{array}$ & $\begin{array}{c}\text { LOD } \\
\left(\mathrm{pg} \mathrm{mL}^{-1}\right)\end{array}$ \\
\hline $\mathrm{Mo}$ & $44.2 \pm 1.3$ & $40.0 \pm 1.2$ & 3 & 20 \\
$\mathrm{Cd}$ & $63.8 \pm 0.9$ & $62.0 \pm 4.0$ & 1 & 5 \\
$\mathrm{Sb}$ & $25.7 \pm 0.7$ & $22.0 \pm 6.0$ & 3 & 5 \\
$\mathrm{Tl}$ & $48.6 \pm 2.5$ & {$[50]^{\mathrm{a}}$} & 5 & 2 \\
$\mathrm{~Pb}$ & $1426 \pm 42$ & $1500 \pm 200$ & 3 & 79 \\
$\mathrm{Bi}$ & $16.5 \pm 1.7$ & $18.0 \pm 2.0$ & 7 & 3 \\
\hline
\end{tabular}

${ }^{a}$ Values in [ ] not certified, given only for information.

$\mathrm{Sb}, \mathrm{Tl}, \mathrm{Pb}$, and $\mathrm{Bi}$ ) and eight lanthanides (La, Ce, Pr, Nd, Sm, Gd, $\mathrm{Dy}$, and $\mathrm{Yb}$ ), were calculated using the following equations:

Eq. (1)

$[\text { R.S.F. }]_{\text {Elem }}=\left[\frac{\text { Int.Elem }_{\text {Ele }}}{\text { Int }_{\text {In }}} \underset{\text { Conc }_{\text {In }}}{\left[\text { Conc }_{\text {Elem }}\right.}\right]_{\text {std }}$

Eq. (2)

$\left[\text { Conc }_{\text {Elem }}\right]_{\text {Samp }}=\left[\frac{\text { Int }_{\text {Elem }}}{\text { Int }_{\text {In }}}\right]_{\text {Samp }} *\left[\frac{\text { Conc }_{\text {In }}}{\text { RSF }}\right]$

In equations 1 and $2, \mathrm{RSF}_{\mathrm{Elem}}=$ relative sensitivity factor of an element, Int $_{\text {Elem }}=$ Intensity of a particular isotope of the element, Int $_{\text {In }}=$ Intensity of ${ }^{115} \mathrm{In}$, Conc $_{\text {Elem }}=$ Con- 
centration of element of interest, Conc $_{\text {In }}=$ Concentration of the indium in the samples. The values used for the standard are those of CRM GSB-7 Tea Leaves and the mul- tielement standard for lanthanides and heavy elements, respectively. The average of the RSFs obtained from duplicate samples of the standards analyzed, bracketing the five

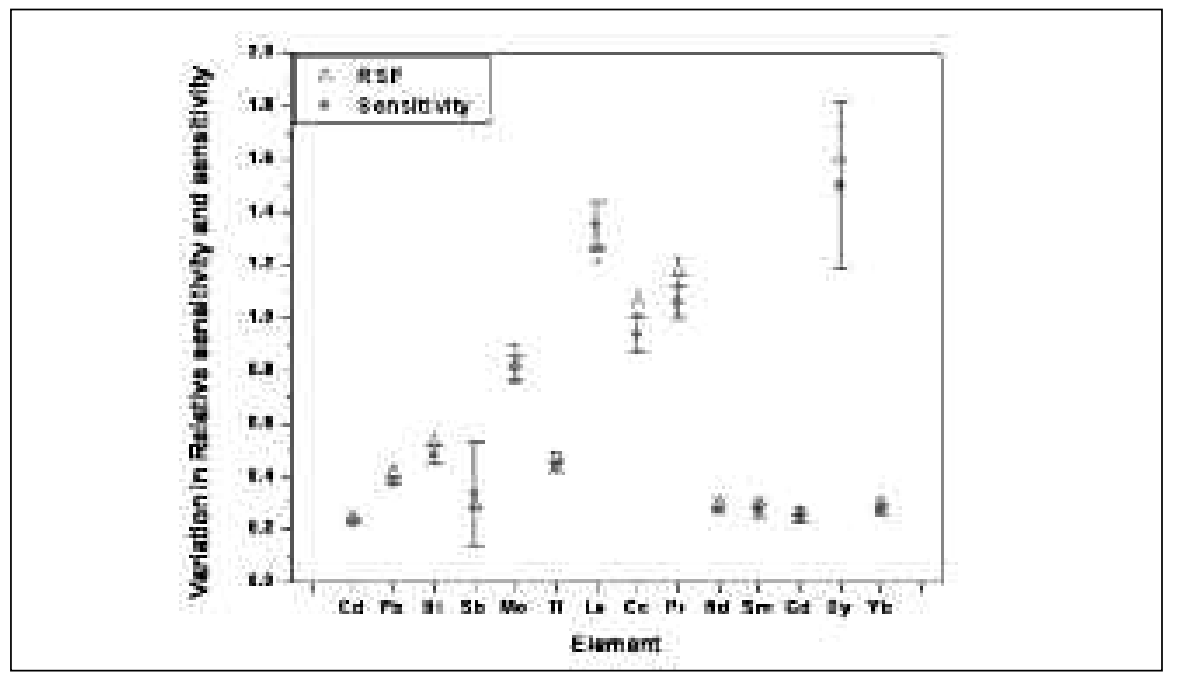

Fig. 2. Comparison between variation in mean relative sensitivity ( $\Delta)$ values w.r $t .{ }^{115}$ In and mean sensitiviy ( $\bullet$ of heavy metals and lanthanides during the period of 7 bours of ICP-MS analysis.

TABLE III samples, were used for calculating the concentrations of different elements in the samples analyzed between two multielement/GSB-7 standards. The RSF values for the elements determined in this work varied within $10 \%$ during the period of the analyses (around seven hours).

\section{Heavy Metal and Lanthanide Content in Indian Tea Samples}

The concentration of an element in the leaves of the same kind of tea can differ widely from samples obtained from different areas. Variability in the uptake of elements by plants and their trace element content reflects, in general, the condition of the soil and the environment where the plants grow. The data with regard to concentration range, mean concentrations, and standard deviations obtained for different elements from the same geographical origin for six heavy metals (Mo,

Comparison of Concentrations of Heavy Metals and Lanthanides in Indian Tea Samples by ICP-MS

\begin{tabular}{cccccccc}
\hline Group & Element & $\begin{array}{c}\text { Conc. } \\
\text { Range } \\
\left(\mathrm{ng} \mathrm{g}^{-1}\right)\end{array}$ & $\begin{array}{c}\text { Assam } \\
(15)^{\mathrm{a}}+(2)^{\mathrm{b}}\end{array}$ & $\begin{array}{c}\text { Darjeeling } \\
(13)^{\mathrm{a}}+(2)^{\mathrm{b}}\end{array}$ & $\begin{array}{c}\text { Munnar } \\
(7)^{\mathrm{a}}+(2)^{\mathrm{b}}\end{array}$ & $\begin{array}{c}\text { Kangra } \\
(8)^{\mathrm{a}}+(6)^{\mathrm{b}}\end{array}$ & $\begin{array}{c}\text { Unknown Market- } \\
\text { Branded Sample } \\
(21)^{\mathrm{a}}\end{array}$ \\
\hline
\end{tabular}

Heavy Metals

$\begin{array}{ccccccc}\mathrm{Mo} & 2.2-74.8 & 44.2 \pm 18.8 & 12.7 \pm 5.44 & 16.7 \pm 1.92 & 28.1 \pm 7.50 & 32.6 \pm 18.2 \\ \mathrm{Cd} & 11.0-53.2 & 42.0 \pm 12.2 & 20.8 \pm 7.75 & 21.0 \pm 4.79 & 30.6 \pm 7.23 & 47.8 \pm 8.31 \\ \mathrm{Sb} & 4.9-34.1 & 14.2 \pm 7.04 & 16.9 \pm 7.13 & 18.6 \pm 4.63 & 17.1 \pm 6.28 & 15.8 \pm 7.93 \\ \mathrm{Tl} & 11-104 & 75.7 \pm 21.2 & 20.4 \pm 10.4 & 18.2 \pm 5.40 & 18.4 \pm 3.93 & 70.5 \pm 26.8 \\ \mathrm{~Pb} & 256-1308 & 614 \pm 196 & 630 \pm 147 & 479 \pm 135 & 877 \pm 246 & 834 \pm 444 \\ \mathrm{Bi} & 1.0-7.7 & 2.65 \pm 1.12 & 5.43 \pm 2.61 & 2.35 \pm 0.84 & 4.85 \pm 1.91 & 4.56 \pm 3.22\end{array}$

Lanthanides

$\begin{array}{ccccccc}\text { La } & 70-794 & 205 \pm 85.2 & 154 \pm 84.8 & 502 \pm 291 & 213 \pm 54.7 & 160 \pm 30.1 \\ \mathrm{Ce} & 137-1091 & 413 \pm 182 & 442 \pm 175 & 482 \pm 123 & 618 \pm 275 & 295 \pm 228 \\ \mathrm{Pr} & 11-206 & 46.9 \pm 28.5 & 70.6 \pm 24.7 & 39.4 \pm 17.5 & 110 \pm 63.4 & 44.5 \pm 34.1 \\ \mathrm{Nd} & 32-290 & 140 \pm 60.1 & 99.1 \pm 48.8 & 180 \pm 75.1 & 136 \pm 36.7 & 172 \pm 122 \\ \mathrm{Sm} & 20-174 & 35.5 \pm 19.4 & 34.3 \pm 17.1 & 57.2 \pm 32.5 & 87.2 \pm 46.4 & 46.1 \pm 26.9 \\ \mathrm{Gd} & 16-166 & 38.5 \pm 21.1 & 53.7 \pm 7.73 & 43.7 \pm 28.6 & 79.6 \pm 47.4 & 38.8 \pm 24.4 \\ \mathrm{Dy} & 1.1-34.6 & 9.01 \pm 4.80 & 19.3 \pm 2.84 & 5.13 \pm 3.48 & 9.39 \pm 2.43 & 27.4 \pm 6.61 \\ \mathrm{Yb} & 7.4-50.6 & 18.2 \pm 6.19 & 18.9 \pm 5.34 & 25.0 \pm 15.5 & 34.0 \pm 13.1 & 23.2 \pm 23.0\end{array}$

Values in parentheses ( ) are the number of samples analyzed.

Mean concentration in $\mathrm{ng} \mathrm{g}^{-1}$.

${ }^{a}$ Processed tea samples.

${ }^{b}$ Virgin tea samples (authentic tea leaves). 
$\mathrm{Cd}, \mathrm{Sb}, \mathrm{Tl}, \mathrm{Pb}$, and $\mathrm{Bi}$ ) and eight lanthanides (La, Ce, Pr, Nd, Sm, Gd, $\mathrm{Dy}$, and $\mathrm{Yb}$ ) found in Indian tea samples and for tea samples of unknown origin in India are given in Table III. It can be seen that the Indian tea samples obtained from different tea-producing regions show the presence of heavy metals at ppb levels.

Among all the tea-producing regions, Assam tea samples showed the highest concentrations of $\mathrm{Cd}$

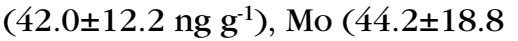
$\left.\mathrm{ng} \mathrm{g}^{-1}\right)$, and $\mathrm{Tl}\left(75.7 \pm 21.2 \mathrm{ng} \mathrm{g}^{-1}\right)$, while Darjeeling and Kangra tea samples showed the highest concentrations of $\mathrm{Bi}\left(5.43 \pm 2.61 \mathrm{ng} \mathrm{g}^{-1}\right)$ and $\mathrm{Pb}\left(877 \pm 246 \mathrm{ng} \mathrm{g}^{-1}\right)$. The concentration of $\mathrm{Sb}$ was found to be comparable in the tea leaves from all the regions. Lead contamination of the soil usually can be attributed to three processes: (a) industrial activities, (b) agricultural activities, and (c) urban activities such as combustion of gasoline. Tea plants are normally grown in highly acidic soil, where $\mathrm{Pb}$ is potentially more bio-available for root uptake. The higher levels of $\mathrm{Pb}$ in tea samples could be attributed to the deposition or accumulation of $\mathrm{Pb}$ on the tea plants from polluted air. Tea plants have a large surface area, which facilitates foliar deposition or uptake of lead from the atmosphere. Phosphate fertilizer application is a significant contributor of trace elements, especially Cd accumulation in soil (17). Repeated application of phosphatic fertilizers may lead to a gradual buildup of $\mathrm{Cd}$ in the agricultural soil over time (5). According to Meeus et al. (18), Cd from phosphate fertilizers constituted more than $50 \%$ of the total input in agricultural lands that were otherwise not heavily polluted or heavily industrialized. Zhang et al. (19) also reported the relationship between extractable heavy metals (Al, $\mathrm{Cu}, \mathrm{Cd}, \mathrm{Pb}$, and $\mathrm{Zn}$ ) in acid soil and metals taken up by tea plants. The results of their studies indicated that the long-term plant- ing of tea can cause soil acidification, and elevated concentrations of the bio-available heavy metals in the soil enhance the risk of their accumulation in tea leaves. YaylaliAbanuz (20) also showed significant correlation between the heavy metal concentrations of soil and those of the tea leaves from Northern Turkey.

It can be seen that the levels of Ce and La varied over a wide range from 137-1091 and 70-794 $\mathrm{ng} \mathrm{g}^{-1}$, respectively, accounting for about $48 \%$ and $19 \%$ of the total rare earth element (REE) content in Indian tea. Nd is the next REE found in the high concentration range of 32.0-290 $\mathrm{ng} \mathrm{g}^{-1}$, accounting for about $13 \%$ of total REEs in Indian tea samples. $\mathrm{Pr}$ and $\mathrm{Sm}$ in Indian tea samples were in the range of 11-206 $\mathrm{ng} \mathrm{g}^{-1}$ and 20-174 $\mathrm{ng} \mathrm{g}^{-1}$, respectively, accounting for only $4-6 \%$ of the total REE content. Gd accounted for $1-3 \%$ of total REE content in Indian tea samples and was in the concentration range of 16-166 $\mathrm{ng} \mathrm{g}^{-1}$.

Other heavier REEs, such as Dy and $\mathrm{Yb}$, were in the concentration range of 1.1-34.6 $\mathrm{ng} \mathrm{g}^{-1}$ and 7.4-50.6 $\mathrm{ng} \mathrm{g}^{-1}$, respectively, contributing to $1-2 \%$ of the total REE content.

A comparison of the REE concentrations in Indian tea with the region of cultivation (see Table III) shows that the concentrations of the eight REEs are in the order of Kangra > Munnar > Darjeeling > Assam. Previous bio-geological investigations demonstrated that the REE content in tea closely corresponds to their concentrations in the soil (21). Also, in recent times in China, rare earth micronutrient fertilizers (REMF) have been applied to the crops to increase yield and quality. The REEs promote peroxidase (POD) activity in tea shoots and enhance the tea shoot biomass. POD protein in tea shoot was found to bind rare earth

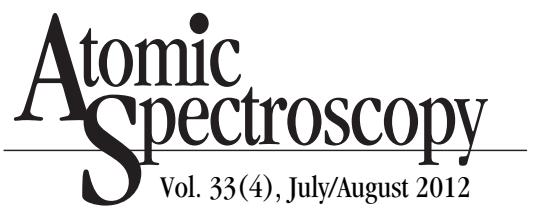

elements, mainly $\mathrm{La}, \mathrm{Nd}$, and Ce, which leads to the accumulation of rare earths in tea plants. Twentyone tea samples (from unknown regions) showed the mean concentration of heavy metals and lanthanides to be within the concentration range of tea samples from known regions.

A comparison of processed and virgin tea samples showed that in processed tea there is a significant increase in $\mathrm{Pb}$ concentration $(\mathrm{Pb}$, $\left.487 \pm 80 \mathrm{ng} \mathrm{g}^{-1}\right)$.

One-way factor analysis of variance (ANOVA) of the data showed statistically significant differences among the concentrations of $\mathrm{Bi}$, Cd, Mo, Pb, Tl, La, Ce, Pr, Sm, Dy, and $\mathrm{Yb}$ in the different tea-producing regions in India ( $\mathrm{p}<0.05)$, while $\mathrm{Sb}, \mathrm{Nd}$, and $\mathrm{Gd}$ did not show any significant difference. The observed variation in the heavy metals content from different regions indicates the level of contamination from these heavy metals and lanthanides in the areas of the tea gardens and can be traced by the analysis of soil, water, and air samples from the respective regions.

\section{Comparison With Other Literature Data}

Table IV presents a comparison of the heavy metal and lanthanide concentration ranges in Indian tea leaves analyzed in the present work with those reported in the literature $(4,8-12,22-24)$. The data from the present work show that the concentration of $\mathrm{Pb}$ in the Indian samples is comparatively lower than that reported in samples from China, Japan, Iran, and Pakistan, while the Cd content in Indian teas is in the range to those reported from Japan, and much lower than those reported from China. The Cd content in Turkish tea samples is comparatively lower than the tea samples from India. Reported concentrations of $\mathrm{Sb}$ and Mo were similar to those of the Indian samples 
TABLE IV

Comparison of Elemental Concentrations in Tea Samples Reported by Other Researchers

\begin{tabular}{|c|c|c|c|c|}
\hline Element & $\begin{array}{l}\text { Conc Range } \\
\text { Present Work } \\
\left(\text { ng g }^{-1}\right)\end{array}$ & $\begin{array}{l}\text { Conc. } \\
\left(\mathrm{ng} \mathrm{g}^{-1}\right)\end{array}$ & $\begin{array}{l}\text { Source of } \\
\text { Tea Leaves }\end{array}$ & References \\
\hline $\mathrm{Bi}$ & $1.0-7.7$ & NA & NA & NA \\
\hline \multirow[t]{4}{*}{$\mathrm{Cd}$} & $11.0-53.2$ & $13-98$ & Japan (139) & Tsushida et al. 2007 \\
\hline & & ND-1590 & China (328) & Shi et al. 2008 \\
\hline & & 50 & Pakistan (14) & Al-Oud 2003 \\
\hline & & $1.46-5.64$ & Turkey (6) & Tokalioglu et al. 2004 \\
\hline Mo & $2.2-74.8$ & $41 \pm 1$ & India (3) & Matsurra et al. 2001 \\
\hline \multirow[t]{5}{*}{$\mathrm{Pb}$} & $256-1308$ & $11-1930$ & Japan (139) & Tsushida et al. 2007 \\
\hline & & $198-6345$ & China (328) & Quin et al 2007 \\
\hline & & $30-14840$ & Pakistan (14) & Al-Oud 2003 \\
\hline & & $50-1270$ & Turkey (6) & Tokalioglu et al. 2004 \\
\hline & & 2300 & $\operatorname{Iran}(5)$ & Karimi et al. 2008 \\
\hline \multirow[t]{3}{*}{$\mathrm{Sb}$} & $4.9-34.1$ & $40.3 \pm 5.2$ & India (3) & Chajduk 2009 \\
\hline & & $37.0 \pm 2.1$ & Ceylon (3) & Chajduk 2009 \\
\hline & & $18.05 \pm 5.5$ & Yunnan (3) & Chajduk 2009 \\
\hline $\mathrm{Tl}$ & $11.0-67.0$ & NA & NA & NA \\
\hline \multirow[t]{6}{*}{$\mathrm{La}$} & $70-794$ & $261 \pm 245$ & India ( 55$)$ & Lagad et al. 2010 \\
\hline & & $241 \pm 23$ & India (3) & Chajduk 2009 \\
\hline & & $160 \pm 24$ & Ceylon (3) & Chajduk 2009 \\
\hline & & $564 \pm 38$ & Yunnan (3) & Chajduk 2009 \\
\hline & & $70-1140$ & Yunnan (150) & Ning et al. 2010 \\
\hline & & $3780-3980$ & India (5) & William et al. 2010 \\
\hline \multirow[t]{5}{*}{$\mathrm{Ce}$} & $137-1091$ & $618 \pm 575$ & India ( 55$)$ & Lagad et al. 2010 \\
\hline & & $386 \pm 32$ & India ( 3 ) & Chajduk 2009 \\
\hline & & $580 \pm 60$ & Yunnan ( 3) & Chajduk 2009 \\
\hline & & $110-1390$ & Yunnan (150) & Ning et al. 2010 \\
\hline & & $3490-4040$ & India (5) & William et al. 2010 \\
\hline \multirow[t]{2}{*}{$\operatorname{Pr}$} & $15.5-206.3$ & $0.01-0.30$ & Yunnan (150) & Ning et al. 2010 \\
\hline & & $1810-1860$ & India (5) & William et al. 2010 \\
\hline \multirow[t]{3}{*}{$\mathrm{Nd}$} & $32-290$ & $137.3 \pm 46.6$ & India (55) & Lagad et al. 2010 \\
\hline & & $10-1170$ & Yunnan (150) & Ning et al. 2010 \\
\hline & & $4.72-7.97$ & India (5) & William et al. 2010 \\
\hline \multirow[t]{3}{*}{ Sm } & $20-174$ & $45.0 \pm 36.7$ & India (55) & Lagad et al. 2010 \\
\hline & & $10-210$ & Yunnan (150) & Ning et al 2010 \\
\hline & & NA & India (5) & William et al. 2010 \\
\hline \multirow[t]{5}{*}{$\mathrm{Yb}$} & $7.4-50.6$ & $21.8 \pm 10.8$ & India (55) & Lagad et al. 2010 \\
\hline & & $56.5 \pm 8.2$ & India (3) & Chajduk 2009 \\
\hline & & $45.0 \pm 7.2$ & Ceylon (3 & Chajduk 2009 \\
\hline & & $48.7 \pm 7.8$ & Yunnan (3) & Chajduk 2009 \\
\hline & & NA & India (5) & William et al. 2010 \\
\hline
\end{tabular}

Comparison of Elemental Concentrations in Tea Samples From Other Researchers. $\mathrm{NA}=$ data not available. Values in ( ) indicates the number of samples analyzed. used in the present work. No literature data are available for comparison regarding $\mathrm{Tl}$ and $\mathrm{Bi}$ concentrations in tea samples.

To date, very few researchers have reported the determination of lanthanides in tea samples. Chajduk (3) reported concentrations of $\mathrm{La}$, $\mathrm{Ce}$, and $\mathrm{Yb}$ in Indian, Ceylon, and Yunnan tea samples employing instrumental neutron activation analysis (INAA) (7). Ning et al. (23) reported REE concentrations in Yunnan tea (China) as follows: La 0.07-1.14 $\mu \mathrm{g} \mathrm{g}^{-1}$, Ce 0.11-1.39 $\mu \mathrm{g} \mathrm{g}^{-1}$, Pr 0.01-0.30 $\mu \mathrm{g} \mathrm{g}^{-1}$, Nd 0.01-1.17 $\mu \mathrm{g} \mathrm{g}^{-1}$, and Sm 0.01-0.21 $\mu \mathrm{g} \mathrm{g}^{-1}$ (23). The lanthanide content in tea samples determined by INAA was also reported by Lagad et al. 2010 (22) and the calculated $t$ values for La (0.09), Ce (0.54), Nd (0.06), Sm (0.96), and $\mathrm{Yb}(1.04)$ were lower than the $t$-critical values of 1.68 for $(\mathrm{P}=0.05)$. This shows that the results of the present study are in good agreement with those obtained by INAA.

The concentration of lanthanides in the Indian tea samples in the present study were determined using the mean relative sensitivity factor (RSF), calculated by employing the standard-sample-standard bracketing methodology during ICP-MS analysis. The variation found in the relative sensitivity factor of each lanthanide resulted in an RSD of $<10 \%$, which proves the stability of the ICP-MS instrument and its parameters during the analysis. The observed stability in mean RSF eliminate polyatomic interferences during analysis and is used for calculating lanthanide concentrations (24-25). Figure 2 shows the variation in mean RSF value over a period of 7 hours of ICP-MS analysis. The concentration of lanthanides obtained in the present work was found to be lower in comparison to the higher, abnormal concentrations reported for Indian tea samples by William et al. 2010 (26). They also employed ICP-MS 
for the determination of lanthanides in tea infusion, but the details of polyatomic interference correction were not given.

\section{Effect of Heavy Metals and Lanthanides in Tea on Human Health}

It is recognized that the amount of trace elements extracted into tea infusions depends principally on whether the compound is strongly bound to the matrix or soluble in the solution (27). Therefore, the amount of minerals in a tea infusion will depend on the extraction efficiency and the total concentration of metals in the tea leaves. Matsurra et al. 2001 (8) classified analyte elements into three groups according to extraction efficiencies: highly extractable heavy elements, e.g., Tl $>55 \%$; moderately extractable heavy elements, e.g., $\mathrm{Mn}, \mathrm{Zn}$, and $\mathrm{Cu} 22-55 \%$; and poorly extractable elements, e.g., Cd, Mo, Pb, Th, U and lanthanides $<20 \%$, which will enter the human body through tea consumption (8). Out of the total heavy metals and lanthanides determined in the present study, with the exception of $\mathrm{Tl}$, all elements showed poor water extraction efficiency $(<20 \%)$ in tea infusion of Darjeeling black and green tea samples. According to the Tea Board of India "Tea consumption report of 2008," an average of $2 \mathrm{~g}$ of tea per capita per day is usually consumed in India (28). The daily intake of heavy metals was calculated (per $2 \mathrm{~g}$ of tea/day) by using the extraction efficiency of heavy metals and lanthanides in Indian tea as reported by Matsurra et al. (2001) (8). The average daily intake of heavy metals was found to be $\mathrm{Cd}$ (11 ng/day), Mo (24.2 ng/day), and $\mathrm{Sb}$ (6.4 ng/day). These values are lower than the Accepted Daily Intake suggested by the WHO (1996, 1997, 1998) (29-32) for Cd $<100 \mu \mathrm{g} / \mathrm{day}$, Mo $<100 \mu \mathrm{g} / \mathrm{day}$, and $\mathrm{Sb}<100 \mu \mathrm{g} /$ day). Bismuth showed a daily intake of $1 \mathrm{ng} / \mathrm{day}$, but the permissible daily intake of $\mathrm{Bi}$ is not available for comparison. Since the extraction efficiency of $\mathrm{Tl}$ is $>55 \%$, the average daily intake of Tl was found to be $35.7 \pm 29.9 \mathrm{ng} / \mathrm{day}$. Some Assam tea samples, containing $75.7 \pm 21.2 \mathrm{ng} \mathrm{g}^{-1}$ of $\mathrm{Tl}$, account for approximately $0.08 \mu \mathrm{g}$ of $\mathrm{Tl}$ in the body, which is below the permissible limit of $5 \mu \mathrm{g} / \mathrm{day}$ recommended by WHO (33). The extraction efficiency of $\mathrm{Pb}$ in tea infusion is about $20 \%$. Higher amounts of $\mathrm{Pb}$ in Assam and Kangra tea samples correspond to an intake of $0.2 \mu \mathrm{g}$ and $0.3 \mu \mathrm{g}$ of $\mathrm{Pb}$, which is much lower than the allowed daily intake value of $\mathrm{Pb}$ (0.2 mg /day) (29-32).

\section{CONCLUSION}

Six potentially toxic heavy metals (Mo, Cd, $\mathrm{Sb}, \mathrm{Tl}, \mathrm{Pb}$, and $\mathrm{Bi}$ ) and eight lanthanides ( $\mathrm{La}, \mathrm{Ce}, \mathrm{Pr}, \mathrm{Nd}$, $\mathrm{Sm}, \mathrm{Gd}, \mathrm{Dy}$, and $\mathrm{Yb}$ ) were analyzed at ppb levels in 77 Indian tea samples using inductively coupled plasma mass spectrometry (ICPMS). An estimation of the daily intake of Cd (11 ng/day), Mo (24.2 ng/day), Sb (6.4 ng/day), Tl (18-24 ng/day, except for some Assam tea samples, $75.7 \mathrm{ng} / \mathrm{day}), \mathrm{Pb}$ (0.2-3 $\mu \mathrm{g} /$ day), and $\mathrm{Bi}(8-16 \mathrm{ng} /$ day) from $2 \mathrm{~g}$ of tea/day and employing the standard procedure for tea infusion shows that the heavy element intake is safe for human consumption. It is lower than the acceptable daily intake values $(\mathrm{Cd}<100 \mu \mathrm{g} / \mathrm{day}$, Mo $<100 \mu \mathrm{g} /$ day, $\mathrm{Pb}<200 \mu \mathrm{g} /$ day), $\mathrm{Sb}<100 \mu \mathrm{g} /$ day, and $\mathrm{Tl}<5 \mu \mathrm{g} /$ day). Some variations in the elemental concentrations were observed among tea samples from different tea-producing regions from northern and northeastern regions of India. The northern and northeastern regions showed higher $\mathrm{Pb}$ concentrations, indicating the effect of environmental factors such as pollution on tea plantations. The $\mathrm{Pb}$ levels in Indian teas are much lower than for tea from China, which may be due to the use of unleaded petrol in India. The data

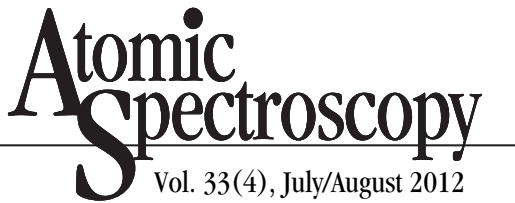

obtained in this study can be useful in developing a method for establishing the geographical origin of tea whether from India or any other location.

\section{ACKNOWLEDGMENT}

The authors express their sincere thanks to Dr. A.C. Udas \& Group from the Analytical Chemistry Division, BARC, for allowing the use of the Clean Environment lab of Class-100 and facilities for the sample preparations. The authors are also thankful to Dr. S. Choudhary for his help in the microwave digestion. One of the authors (RAL) thanks the Department of Atomic Energy for financial assistance under the Bhabha Atomic Research Centre - University of Mumbai collaboration scheme.

Received February 13, 2012.

\section{REFERENCES}

1. J. Pirzada, W. Shaikh, K.U. Ghani and K. A. Laghari, Sindh Univ. Res. Jour. 41, 15 (2009).

2. F. Qin and W. Chen, Bull. Environ. Contam. Toxicol.78, 118 (2007).

3. B. Kalandadze, Agron. Research 1, 131 (2003).

4. G. Qiu, W. Li, X. Li, W. Zhou and C. Yang, J. Rare Earth, 23, 554(2005).

5. A. Kabata-Pendias and H. Pendias, Trace elements in soils and plants. Boca Raton, FL, USA, CRC Press (2001).

6. S.M. Ding, T. Liang, C.S. Zhang, L.J. Wang and Q. Sun, Pedosphere 16, 82 (2006).

7. E. Chajduk, Chem. Anal. Warsaw 54, 841(2009).

8. A. Matsurra, F. Hokura, A. Katsuki and A. Itoh, Anal. Sci. 17, 391(2001). 
9. T. Tsushida and T. Takeo, J. Sci. Food Agric. 28, 255 (2007).

10. Y. Shi, J. Ruan, L. Ma, W. Han and F. Wang, J. Zhejiang Univ. Sci. B, 9, 265 (2008).

11. S. S. AL-Oud, Pak. J. Biol. Sci. 6, 208 (2003).

12. S. Tokalioglu and S. Kartal, Instrum. Sci. Technol. 32, 387 (2004).

13. M.A. Moghaddam, A.H. Mahvi, A.R. Asgari, M. Yonesian, G.H. Jahed and S.H. Nazmara, Environ. Monit. Assess. 144, 23 (2008).

14. J.O. Duruibe, M.O.C. Ogwuegbu and J.N. Egwurugwu, Int. J. Phys. Sci. 2,112 (2007).

15. R.A. Young, Toxicity Profiles: Toxicity Summary for Cadmium, Risk Assessment Information System, RAIS, University of Tennessee (2005). (rais.ornl.gov/tox/profiles/ cadmium.shtml).

16. C.H. Evans, Biochemistry of the Lanthanides, Plenum Press, New York, p.339 (1990),

17. M. Cupit, O. Larsson, C. de Meeus, G.H. Eduljee and M. Hutton, Sci. Total Environ. 291, 189 (2002).

18. C., Meeüs, G.H., Eduljee and M. Hutton, Sci. Total Environ. 291, 167 (2002).

19. M. Zhang and L. Fang, Comm. Soil Sci. Plant Anal. 38, 1 (2006).

20. G. Yaylal1-Abanuz and N. Tuysuz, Environ. Earth Sci. 59, 131 (2009).

21. R. Street, O. Drabek, J. Szakova and L. Mladkowa, Food Chem. 104, 1662 (2007)

22. R. A. Lagad, D. Alamelu, R. Acharya and S. K. Aggarwal, J. Radioanal. Nucl. Chem. 288, 613 (2011).

23. P. Ning, C. Gong, Y. Zhang and $K$ Guo, J. Rare Earths, 28, 636 (2010).

24. N.M. Raut, L.S. Huang, K.C. Lin and S.K. Aggarwal, Anal. Chim. Acta 530, 91 (2005).

25. N.M. Raut, L.S. Huang, S.K. Aggarwal, K.C. Lin, J. Chin. Chem. Soc. 52, 589 (2004).

26. J.R. Williams, A.E. Pillai and S.K. AlAsmi, Res. J. Chem. Environ. 14, 72 (2010).
27. H. Jin, A. Sabarudin, M. Oshima and S. Motomizu, Bunseki Kagaku, 58, 699 (2009).

28. Annual Report of Tea Board of India 2008, (http://www.teaboard. gov.in/pdf/stat/Consumption.pdf).

29. WHO (World Health Organization) Quality Control Methods for Medicinal Plant Materials, WHO, Geneva, Switzerland (1998).

30. WHO (World Health Organization) Guideline for Drinking Water Quality. Second Edition, Recommendations WHO, Geneva, Switzerland (Vol.1, 1997).

31. WHO (World Health Organization) Trace Elements in Human Nutrition and Health, WHO, Geneva, Switzerland (1996).

32. JECFA (Joint FAO/WHO Expert Committee on Food Additives). Evaluation of Certain Food Additives and Contaminants. Forty-first Report of the Joint FAO/WHO Expert Committee on Food Additives, Geneva, Switzerland.

33. World Health Organization (WHO) Criteria Document on Thallium. (http://www.lead.org.au/Lanv7n3/ L73-11.html) 